\title{
Archaeological Evidence of the Use of the Horse by Caddo Indian Peoples
}

Timothy K. Perttula

Heritage Research Center, Stephen F. Austin State University

Follow this and additional works at: https://scholarworks.sfasu.edu/ita

Part of the American Material Culture Commons, Archaeological Anthropology Commons, Environmental Studies Commons, Other American Studies Commons, Other Arts and Humanities Commons, Other History of Art, Architecture, and Archaeology Commons, and the United States History Commons

Tell us how this article helped you.

This Article is brought to you for free and open access by the Center for Regional Heritage Research at SFA ScholarWorks. It has been accepted for inclusion in Index of Texas Archaeology: Open Access Gray Literature from the Lone Star State by an authorized editor of SFA ScholarWorks. For more information, please contact cdsscholarworks@sfasu.edu. 


\section{Archaeological Evidence of the Use of the Horse by Caddo Indian Peoples}

Creative Commons License

(c) (i) (8)

This work is licensed under a Creative Commons Attribution-NonCommercial 4.0 International License 


\title{
Archaeological Evidence of the Use of the Horse by Caddo Indian Peoples
}

\author{
Timothy K. Perttula
}

\section{INTRODUCTION}

The introduction of the horse to the Americas by Europeans, particularly the Spanish, after 1492 played a very important role in Native American history and societal change. As Peter Mitchell (2015:7) has commented in his book Horse Nations: "the horse was so very widely introduced to population across the world after 1492. It can thus provide a constant against which to evaluate the many changes that those populations experienced after European contact, while highlighting the 'radically different meanings and impacts in distinctive cultures' that its arrival heralded." Among the Caddo Indian peoples, the horse was introduced in the late 1600s from Mexico (Mitchell 2015:Figure 3.6) as well as the Jumano tribe of the Southern Plains (Mitchell 2015:98), leading to the development of new means to "trade, move, and raid," and move equipment, as mounted warfare came to dominate the Southern Plains of North America after about the early 1680s (Mitchell 2015:81-82). By 1719, the Caddo were domesticating feral horses (La Vere 1998:62), as the horse became well integrated into their farming economies. By this time, the horse was the prime exchangeable commodity for Caddo societies south of the Red River.

The Jumano Juan Sabeata had described the Tejas or Hasinai Caddo groups in the early 1680s as "a settled people [who]...raised grain in such abundance that they even fed it to their horses" (Bolton 1920:314). In addition to the horses, the Caddo also obtained horse gear, such as bridles and saddles. When La Salle came to East Texas in 1686, after his expedition to find the Mississippi River had failed along the Texas Gulf Coast, he purchased several horses from the Hasinai Caddo; when he set out for the Mississippi River in 1687, he did so on horses previously purchased from the Caddo (Joutel 1906:113). Father Anastasius Douay, who accompanied La Salle, said that horses were common property among the Caddo and could be purchased for a single iron hatchet (Hackett 1931-1946, Volume 1, para. 361-363). In 1690, when Henri de Tonti was in Kadohadacho villages along the Red River in northeastern Texas, he commented that they had 30 horses, which the Kadohadacho called cavali (after caballo, a horse in Spanish) (Perttula 1992:11). Furthermore, the Nabedache Caddo in East Texas "possessed them in such numbers that there were four or five about each house" (Griffith 1954:145). The livestock brought by the Spanish to East Texas became part of the Hasinai herd after the missions were abandoned in 1693.

By this time, the Caddo had already begun a profitable trade in salt, pelts, and horses with French Louisiana and Illinois colonies (Giraud 1974:343); in 1714, the Frenchman St. Denis established the Natchitoches post at the abandoned 1702 Natchitoches village to commence formal French involvement in trade with Native Americans (Swanton 1946:737-738). For the sale of horses at the French post at Natchitoches, the Hasinai Caddo received firearms, powder and lead balls, hatchets, knives, hoes, glass beads, mirrors, cloth, garments, and alcohol (Surrey 1916:282). By about 1716, "the Hasinai and the Cadohadachos marked, respectively, the saturated frontier of horses moving eastward, and of muskets moving westward in trade" (Perttula 1992:202). As late as 1800, the Barr and Davenport trading house in Spanish Nacogdoches, Texas, acquired 500 horses from the Hasinai Caddo groups and immigrant Indians living in East Texas (see Jackson 1986:472). 


\section{Archaeological Evidence}

Despite the Caddo's long use of the horse, at the present time there are only three ancestral Caddo sites that have direct archaeological evidence of the use of the horse by Caddo peoples (Figure 1). All three of the sites are in the Red River basin, in either East Texas or Northwest Louisiana.

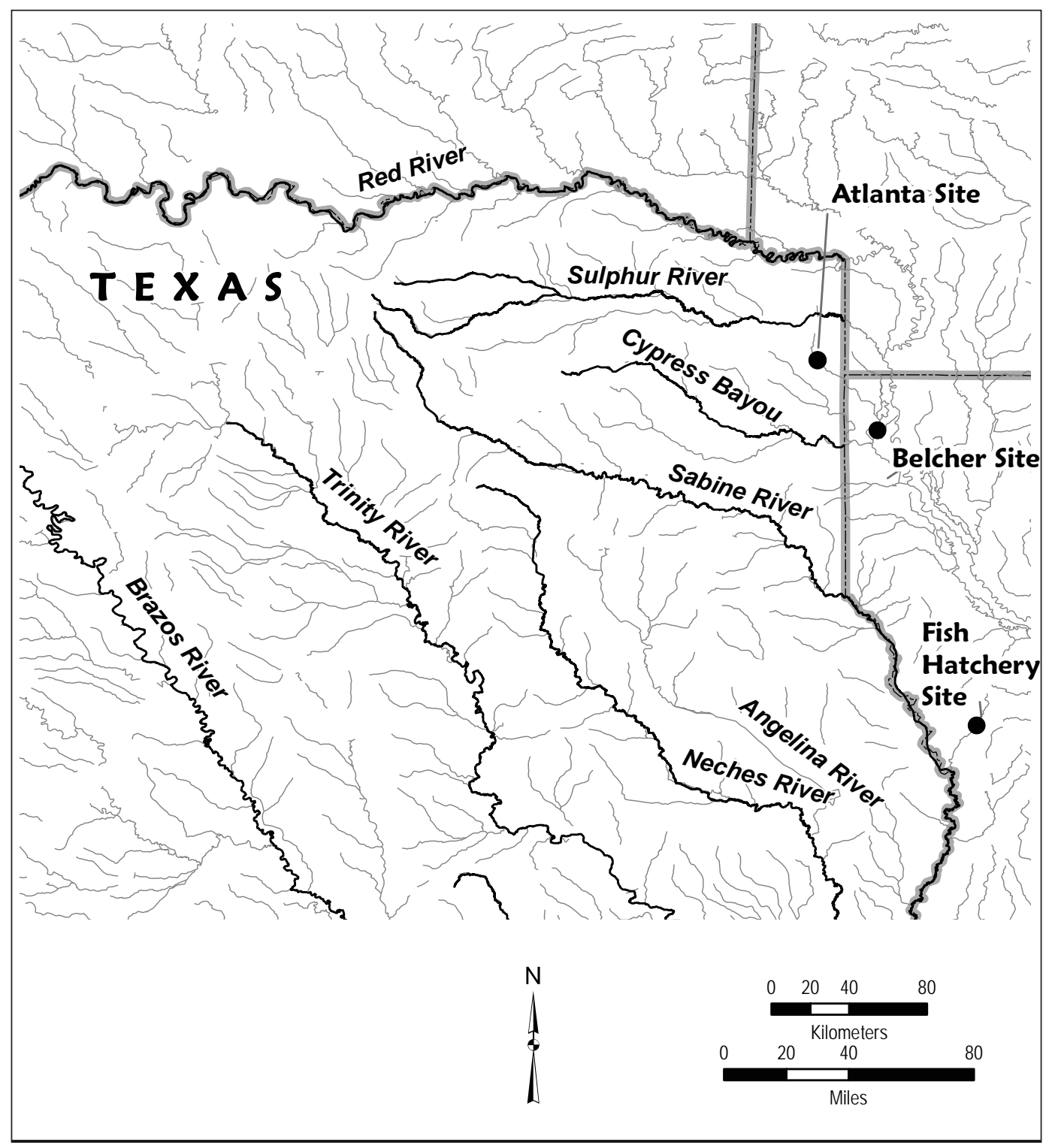

Figure 1. Location of Caddo archaeological sites with evidence of use of the horse.

The first of the archaeological sites is the Belcher site (16CD13). Excavations in Mound B more than 60 years ago recovered one horse phalanx (Webb 1959:180). Other than noting that "bones of horse, cow, and pig...were probably incorporated in the superficial layers of debris" in the mound (Webb 1959:180), Webb provides no specific provenience information for the horse bone. If the bone is not modern in age, then it suggests that the horse bone is part of the very latest Belcher phase occupation at the site, perhaps dating in the late 1600 s or very early 1700 s (cf. Kelley 2012). 
The second site is the Fish Hatchery site in Natchitoches Parish, Louisiana (Walker 1935), not far from the French post of Natchitoches. This $18^{\text {th }}$ century Natchitoches Caddo site on Cane River, an old channel of the Red River, is a large cemetery ( $>100$ burials). Amidst the ancestral Caddo burials were two horse burials (Walker 1935:Figure 1). According to Walker (1935:3):

Most surprising of all was the finding of two horse skeletons, each with a large earthen bowl placed near the head. The bowls were of plain ware about a foot and a half in diameter and half an inch thick.

Bolton (1987:153) mentioned the third Caddo site with archaeological evidence of the use of the horse. He noted that "the excavation of a grave at Atlanta, Texas, in the Caddo country, gives ground for thinking that after the coming of the horse, the warrior's steed was buried with him." Although the specific site is not mentioned by Bolton, it is suspected that the site is in the same area as other late $17^{\text {th }}$ to early $18^{\text {th }}$ century Nasoni Caddo sites along the Caddo trace in Cass County, Texas, such as Goode Hunt (41CS23), Clements (41CS25), A. P. Fourche, and R. A. Simpson on Black Bayou and Black Cypress Bayou (Perttula et al. 2010).

A fourth Historic Caddo site that may have evidence of use of the horse is the Susie Slade site (41HS13) on Potter's Creek in the mid-Sabine River basin. This Nadaco Caddo site was used as a cemetery during much of the $18^{\text {th }}$ century and the early $19^{\text {th }}$ century. The site records at the Texas Archeological Research Laboratory at The University of Texas at Austin indicate that the "bones of a horse" were found buried at the site when excavations were done in the early 1960s by local collectors.

\section{CONCLUSIONS}

Historical and ethnohistorical sources indicate that the horse was important in Caddo societies and economic pursuits by the early 1680 s, and became even more so in later years as the horse was a prime Caddo trade product traded with Europeans for many different kinds of commodities. Mitchell (2015:130) suggests that these horse burials on Caddo sites "attest to the high value that horses held, and we know that among Caddoan speakers both breeding and trading horses were sources of male prestige." And perhaps, these burials marked the graves of important horse traders in Natchitoches and Nasoni Caddo communities.

The virtual absence of horse bones in midden or habitation deposits in Caddo sites also indicates that they were not a source of meat to Caddo populations, as they were to many Southern Plains bison-hunting groups (Mitchell 2015:126), but were much more important in enhancing Caddo trading opportunities with Europeans and other Native American communities, such as the Choctaw, particularly in the peltry, horse, gun, and salt trades through much of the $18^{\text {th }}$ century (Perttula 1994). In this trade, Caddo communities supplied food products, material items, and marketable goods such as horses, pelts, and bear grease in return for European goods. Having the horse also allowed Caddo groups to engage in the long distance exploitation of Southern Plains bison herds after the 1680s.

\section{ACKNOWLEDGEMENTS}

Thanks to Bob D. Skiles for finding a PDF of the Walker (1935) publication. 


\section{REFERENCES CITED}

Bolton, H. E.

1920 The Spanish Borderlands: A chronicle of Old Florida and the Southwest. Yale University Press, New Haven.

1987 The Hasinais: Southern Caddoans as seen by the Earliest Europeans. University of Oklahoma Press, Norman.

Giraud, M.

1974 Histoire de la Louisiane Francaise, Vol. 4, La Louisiana après le system de Law, 1721-1723. Presses Universitaires de France, Paris.

Griffith, W. J.

1954 The Hasinai Indians of East Texas as seen by Europeans, 1687-1772. Philological and Documentary Studies, Volume 2, No. 3. Middle American Research Institute, Tulane University, New Orleans.

Hackett, C. W. (editor and translator)

1931-1946 Pichardo's Treatise on the Limits of Louisiana and Texas. 4 Vols. University of Texas Press, Austin.

Jackson, J.

1986 Los Mestenos: Spanish Ranching in Texas, 1721-1821. Texas A\&M University Press, College Station.

Joutel, $\mathrm{H}$.

1906 An Historical Journal of the Late Monsieur de La Salle's Last Voyage into North America to Discover the Mississippi River. Edited by H. R. Stiles, reprint. Joseph McDonough, New York.

Kelley, D. B.

2012 The Belcher Phase: Sixteenth- and Seventeenth-Century Caddo Occupation of the Red River Valley in Northwest Louisiana and Southwest Arkansas. In The Archaeology of the Caddo, edited by T. K. Perttula ands C. P. Walker, pp. 411-430. University of Nebraska Press, Lincoln.

La Vere, D.

1998 The Caddo Chiefdoms: Caddo Economics and Politics, 700-1835. University of Nebraska Press, Lincoln.

Mitchell, P.

2015 Horse Nations: The Worldwide Impact of the Horse on Indigenous Societies Post-1492. Oxford University Press, Oxford.

Perttula, T. K.

1992 "The Caddo Nation": Archaeological \& Ethnohistoric Perspectives. University of Texas Press, Austin.

1994 French and Spanish Colonial Trade Policies and the Fur Trade among the Caddoan Indians of the Trans-Mississippi South. In The Fur Trade Revisited: Selected Papers of the Sixth North American Fur Trade Conference, Mackinac Island, Michigan, 1991, edited by J. S. H. Brown, W. J. Eccles, and D. P. Heldman, pp. 71-91. Michigan State University Press and Mackinac State Historic Parks, East Lansing and Mackinac Island, Michigan.

Perttula, T. K., B. Nelson, R. L. Cast, and B. Gonzalez

2010 The Clements Site (41CS25): A Late 17th to Early 18th Century Nasoni Caddo Settlement and Cemetery. Anthropological Papers No. 92. American Museum of Natural History, New York City.

Surrey, N. M. M.

1916 The Commerce of Louisiana during the French regime, 1699-1763. Studies in History, Economics, and Public Law, Volume 71. Columbia University, New York. 
Swanton, J. R.

1946 The Indians of the Southeastern United States. Bulletin 137. Bureau of American Ethnology, Smithsonian Institution, Washington, D.C.

Walker, W. M.

1935 A Caddo Burial Site at Natchitoches, Louisiana. Miscellaneous Collections 94(14):1-15. Smithsonian Institution, Washington, D.C.

Webb, C. H.

1959 The Belcher Mound, a Stratified Caddoan Site in Caddo Parish, Louisiana. Memoirs No. 16. Society for American Archaeology, Salt Lake City. 